\title{
Effect of Serratia entomophila and diazinon applied with seed against grass grub populations on the North Island volcanic plateau
}

\author{
S.M. Zydenbos ${ }^{1}$, R.J. Townsend ${ }^{1}$, P.M.S. Lane ${ }^{2}$, S. Mansfield ${ }^{1,3}$, M. O'Callaghan ${ }^{1}$, \\ C. van Koten ${ }^{1}$ and T.A. Jackson ${ }^{1}$ \\ ${ }^{1}$ AgResearch, Lincoln Science Centre, Private Bag 4749, Christchurch 8140, New Zealand \\ ${ }^{2}$ Ballance Agri-Nutrients, Tauranga, New Zealand \\ ${ }^{3}$ Bio-Protection Research Centre, Lincoln University, Lincoln, New Zealand \\ Corresponding author: sue.zydenbos@agresearch.co.nz
}

\begin{abstract}
The bacterial biocontrol agent, Serratia entomophila, and the insecticide diazinon, were applied as separate granular formulations with ryegrass seed and compared with a seed-only control treatment on three pastures of different ages and composition on the North Island volcanic plateau. In the first 2 years, diazinon and S. entomophila significantly reduced healthy grass grub populations compared with the control. However, by the third year populations in the diazinon treatments had recovered and were significantly higher than in S. entomophila or control plots. Grass grub populations were reduced by disease outbreaks after S. entomophila was applied, which infected $>40 \%$ of grass grub larvae in the treated plots in year two. Bacterial extraction from soil a year after application confirmed establishment and persistence of $S$. entomophila in treated plots. Visual positive pasture growth responses were noted in both the $S$. entomophila- and diazinon-treated plots.
\end{abstract}

Keywords Costelytra zealandica, amber disease, biopesticide.

\section{INTRODUCTION}

The New Zealand grass grub (Costelytra zealandica) is one of New Zealand's major pasture pests (Garnham \& Barlow 1993) and causes damage to pasture plants by feeding on their roots. Devastating outbreaks of the pest can follow large-scale land changes, such as implementation of irrigation schemes or conversion from forestry (Jackson et al. 2012). More commonly, grass grub damage is seen in pastures after very dry summers or cultivation, where grass grub larval populations steadily increase after sowing, reaching damaging levels 2-4 years after establishment of the new pasture (East \& Kain 1982).

One of the reasons for large outbreak populations of grass grub 2-4 years after a disruptive event is the loss of entomopathogenic micro-organisms from the soil (O'Callaghan et al. 1999). A wide range of naturally-occurring soil microorganisms is reported to cause mortality in grass grub larvae (Glare et al. 1993). A key pathogen is the soil dwelling bacterium Serratia entomophila, which causes natural epizootics of amber disease in grass grub larvae 
(Jackson et al. 1993; O'Callaghan et al. 1999). The bacterium has been developed as a commercial microbial control agent (Jackson et al. 1992). The product was first marketed as Invade ${ }^{\circ}$ (liquid formulation) and further research has led to development of a granular formulation (Bioshield ${ }^{\mathrm{Tw}}$ ) with greatly improved shelf life under ambient conditions (Johnson et al. 2001). Field trials previously conducted at 18 sites throughout New Zealand indicated the granular formulation could be applied successfully using conventional machinery. The treatment resulted in a $20 \%$ increase in the incidence of amber disease in treated grass grub populations, compared to untreated populations (Townsend et al. 2004). Levels of disease in grass grub populations of $15-20 \%$ within 2 months of treatment were sufficient to establish a disease epizootic, resulting in the subsequent decline in the grass grub population (Jackson et al. 1992).

A standard chemical option for grass grub control in pastures has been to apply diazinon (AgPest 2016). There are a number of concerns about this practice, including the growing consumer resistance to the use of pesticides in food production systems, the short-term nature of grass grub control using diazinon (Lauren et al. 1990) and the recent decision by New Zealand's EPA to deregister diazinon for use in pasture by 2028 (Environmental Protection Authority 2016).

The aim of this research was to compare the efficacy of diazinon and a commercial formulation of S. entomophila against grass grub for 3 years in recently-sown and established pastures.

\section{MATERIALS AND METHODS}

\section{Paddock history and application of treatments}

The three trial sites were all located within $7.5 \mathrm{~km}$ of each other on Landcorp Farm Ltd's Rangitaiki Station (38.844107E, 176.461684S). This region has an annual rainfall of approximately $1500 \mathrm{~mm}$ per year (1217, 1674 and $1682 \mathrm{~mm} \mathrm{2009-11)}$ and is located at an altitude of $720 \mathrm{~m}$ above sea level. All sites were badly infested with grass grub. Occasional manuka beetle and Tasmanian grass larvae were noted. Site 2 A13 had a sheep- and beef-grazed pasture comprised of a vigorous 2-year-old tall fescue sward containing very little clover or weeds but with some bare ground between the fescue plants. Site 2A11 was a 5-year-old slightly run out sheep- and beef-grazed pasture comprising a ryegrass base with a significant component of bare ground and weed species. The third site, paddock 3B21 was a 3-year-old deer-grazed pasture with a vigorous ryegrass/clover-based sward with only minor bare ground or weed components. All sites had volcanic ash and pumice derived soils.

Trials were laid out with the treatments arranged in four randomised blocks at each site with plot sizes of $10 \mathrm{~m}$ x $20 \mathrm{~m}$. All treatments were applied using a Landcorp-supplied, custom-designed air seeder drill with the drilling supervised by AgResearch field staff.

Treatments at all three sites were applied on the same day - 19 March 2009. Bioshield ${ }^{\mathrm{TM}}$ drillable granules were supplied by Ballance Agri-Nutrients Ltd and were drilled at the recommended rate of $30 \mathrm{~kg} / \mathrm{ha}$, equivalent to $4 \times 10^{13}$ colony forming units (cfu)/ha of S. entomophila (Serratia treatment). Diazinon granules (Gesapon 20G) were drilled at the recommended rate of $1.1 \mathrm{~kg}$ active ingredient/ha (diazinon treatment). Bare ryegrass seed $(7.5 \mathrm{~kg} / \mathrm{ha})$ was drilled with all treatments, including the control.

\section{Sampling of trial sites}

Samples were taken from each trial site at 8 weeks after treatment application (14 May 2009) and again on 25 May 2010 and 25 May 2011 to determine grass grub population levels and the percentage of amber disease present in the population. Sampling was carried out by taking 25 soil cores $(6.2 \mathrm{~cm}$ diameter) per plot to a depth of $15 \mathrm{~cm}$. Samples were hand sorted in the field and all grass grub larvae recovered were placed in individual cells of 24-well tissue culture trays. These trays were then sent to AgResearch, Lincoln, where disease levels were assessed using a standard feeding bioassay (Jackson et al. 1993; Jackson \& Saville 2000).

Soil samples, comprising 40 random cores pooled for each plot $(2.5 \mathrm{~cm}$ diameter to a depth of $8 \mathrm{~cm}$ ), were collected in May 2010 to 
assess survival and carry-over of S. entomophila. Enumeration of $S$. entomophila population levels was carried out using standard laboratory methods (O'Callaghan \& Jackson 1993a).

On 26 May 2010, two assessors carried out independent assessments of pasture damage on the plots for Site 3B21. Damage was scored on a 1-10 scale, with a score of 10 being the most damaged. Correlation between the two assessors was high $(\mathrm{r}=0.87)$ and so mean values were used for statistical analysis. In May 2011, damage assessments were made at Sites 3B21 and 2A11. Because little damage was seen at Site 2A13, assessments were made of pasture vigour on a 1-3 scale, with a score of 3 being the most vigorous.

In May 2011 pasture composition was assessed using the method of Fraser et al. (2011). This method records the presence of grass, clover and weed species plus bare ground, in twenty-five $10 \mathrm{~cm}$ diameter turf cores sampled from each plot.

\section{Statistical analysis}

Grass grub populations were corrected to numbers of healthy larvae $/ \mathrm{m}^{2}$ by adjusting the counts in the field with the incidence of disease measured after the laboratory feeding assay. Analysis was performed individually for each site. Grass grub populations, pasture composition and pasture damage assessments were compared using a generalised linear modelling (GLM) approach, assuming the values followed treatment-specific negative binomial distributions through log link.
In the case of soil S. entomophila levels, Fisher's exact test was used because of zero values in some treatments. Differences in levels of amber disease between treatments were compared using logistic regression.

\section{RESULTS \\ Amber disease}

In 2009 after the treatments had been applied in the field, the incidence of grass grubs displaying amber disease symptoms using the laboratory feeding assay was low in control plots $(<3 \%)$ at all three sites (Table 1). Levels of amber disease were also low in diazinon-treated plots $(<3 \%)$. The impact of the Serratia granules was obvious, with significantly higher $(\mathrm{P}<0.001)$ levels of amber disease in all sites.

In the second year after treatment application, amber disease had increased in all control plots, but remained very low $(<1 \%)$ in the diazinon-treated plots. Amber disease levels had reached even higher levels in the Serratia-treated plots, still significantly greater $(\mathrm{P}<0.001)$ than the control plots.

By May 2011, amber disease levels in Serratiatreated plots had decreased compared to previous years, but were still significantly greater $(\mathrm{P}<0.01)$ than the control plots at all three sites. Amber disease in diazinon-treated plots was lower than control plots at two of the three sites.

Table 1 The percentage of grass grub larvae assessed as being infected with amber disease after a feeding bioassay for three sites over 3 years in Serratia-treated, diazinon-treated and control plots. Values are Mean \pm SEM. Treatments followed by the same letter are not significantly different $(\mathrm{P}>0.05)$ for each site/year combination.

\begin{tabular}{crrr}
\hline & Site 3B21 & Site 2A11 & Site 2A13 \\
\hline $\mathbf{2 0 0 9}$ Serratia & $30.0 \pm 1.1 \mathrm{a}$ & $22.7 \pm 1.3 \mathrm{a}$ & $13.4 \pm 1.4 \mathrm{a}$ \\
Diazinon & $2.9 \pm 0.1 \mathrm{~b}$ & $1.0 \pm 0.4 \mathrm{~b}$ & $0 \pm 0 \mathrm{~b}$ \\
Control & $2.7 \pm 0.1 \mathrm{C}$ & $0.7 \pm 0.2 \mathrm{~b}$ & $0 \pm 0 \mathrm{~b}$ \\
$\mathbf{2 0 1 0}$ & & & \\
Serratia & $40.3 \pm 1.1 \mathrm{a}$ & $44.4 \pm 1.3 \mathrm{a}$ & $17.8 \pm 1.0 \mathrm{a}$ \\
Diazinon & $0.7 \pm 0.2 \mathrm{~b}$ & $1.0 \pm 0.4 \mathrm{~b}$ & $0.9 \pm 0.3 \mathrm{~b}$ \\
Control & $10.2 \pm 0.7 \mathrm{c}$ & $5.3 \pm 0.5 \mathrm{c}$ & $6.5 \pm 0.5 \mathrm{c}$ \\
$\mathbf{2 0 1 1}$ & & & \\
Serratia & $28.4 \pm 1.7 \mathrm{a}$ & $8.0 \pm 1.2 \mathrm{a}$ & $31.2 \pm 1.1 \mathrm{a}$ \\
Diazinon & $10.6 \pm 1.0 \mathrm{~b}$ & $0.6 \pm 0.2 \mathrm{~b}$ & $13.2 \pm 0.7 \mathrm{~b}$ \\
Control & $12.6 \pm 1.7 \mathrm{~b}$ & $4.6 \pm 0.9 \mathrm{c}$ & $18.3 \pm 1.0 \mathrm{c}$ \\
\hline
\end{tabular}




\section{Grass grub populations}

In the treatment year (2009), grass grub populations in control plots varied between the three sites, ranging from 209-429 larvae $/ \mathrm{m}^{2}$. Grass grub populations in May, 2 months after treatment application, were significantly lower $(\mathrm{P}<0.05)$ in diazinon-treated than control plots at two of the three sites (Figure 1). Grass grub populations were lower in Serratia-treated than control plots, with this difference being statistically significant $(\mathrm{P}<0.05)$ at one site $(3 \mathrm{~B} 21)$.

One year after treatment, grass populations were significantly lower $(\mathrm{P}<0.01)$ in diazinontreated than control plots at all three sites. In Serratia-treated plots, populations were significantly lower $(\mathrm{P}<0.05)$ than control plots at two of the three sites, with no significant difference $(\mathrm{P}=0.075)$ at the third site $(2 \mathrm{~A} 13)$.

Two years after treatment, grass grub populations in control plots ranged from 85-305 larvae $/ \mathrm{m}^{2}$, and had decreased considerably compared to the treatment year at two of three sites. In contrast to previous years, grass populations were higher in diazinon-treated than Serratia-treated or control plots, with this difference being statistically significant $(\mathrm{P}<0.05$ and $\mathrm{P}<0.001)$ at two of the three sites. In Serratia-treated plots, populations were the same as control plots at two of the three sites, and significantly higher $(\mathrm{P}<0.05)$ at one site $(3 \mathrm{~B} 21)$.

\section{Serratia entomophila in soil}

One year after the application of the treatments, the levels of $S$. entomophila were significantly greater in Serratia-treated than diazinon-treated plots at all sites (Table 2). Serratia-treated plots had significantly higher levels of $S$. entomophila than the control plots at the $2 \mathrm{~A} 13$ site.

\section{Pasture damage and composition}

Pasture damage was scored visually for the 3B21 site in May 2010, 1 year after treatment application. There was significantly $(\mathrm{P}<0.05)$ greater damage in the control than the Serratia-treated and diazinontreated plots (Table 3). In 2011, Serratia-treated plots were less damaged than the control and diazinon-treated plots for the 3B21 and 2A11 sites, while the Serratia-treated plots tended to have more vigorous pasture growth at the $2 \mathrm{~A} 13$ site.

Assessments were made of the pasture composition in the final year of the trial. At

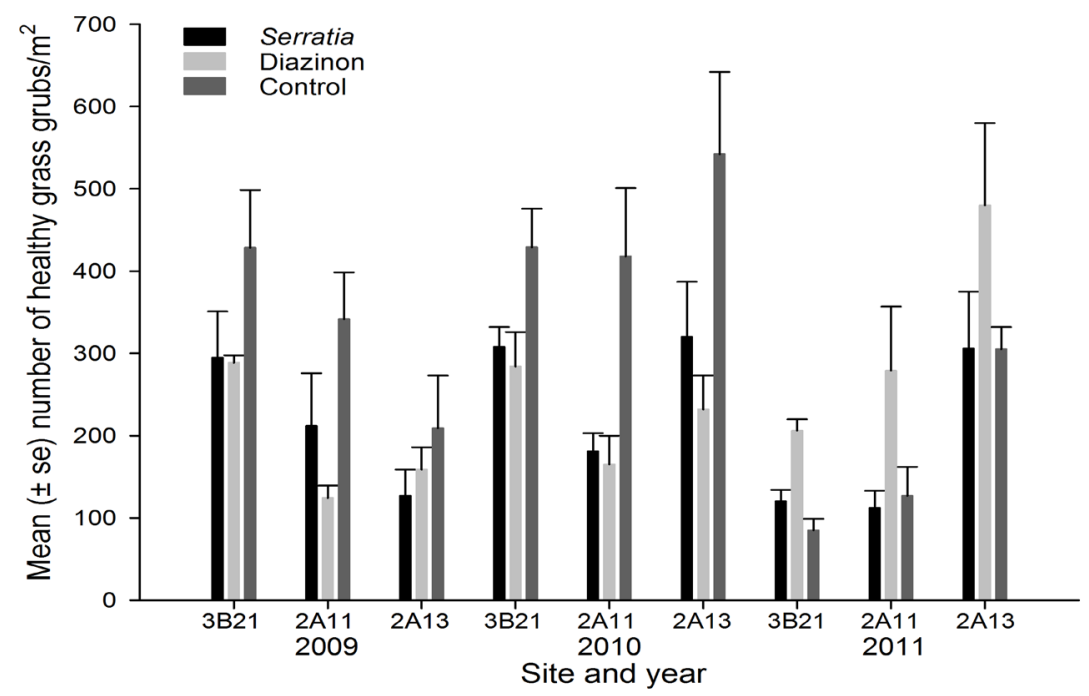

Figure 1 Populations of healthy grass grubs $\left(\right.$ number $/ \mathrm{m}^{2}$ ) at three sites over 3 years for Serratia-treated, diazinon-treated and control plots. 
the 3B21 site, the only statistically significant difference $(\mathrm{P}=0.018)$ was a higher weed presence in diazinon-treated (weeds present in $74 \%$ of samples) than Serratia-treated and control plots (weeds present in $58 \%$ of samples for both treatments).

At the 2A11 site, significant differences were recorded for the presence of ryegrass and other grasses. Presence of ryegrass was higher in Serratia-treated $(57 \%)$ than diazinon-treated (41\%) plots $(\mathrm{P}=0.041)$, with control plots being intermediate (54\%). Conversely, the presence of other grasses was higher $(\mathrm{P}<0.001)$ in diazinontreated (78\%) than Serratia-treated (48\%) plots, with control plots again being intermediate $(63 \%)$.

The only difference $(\mathrm{P}<0.05)$ in pasture composition at the $2 \mathrm{~A} 13$ site was a lower presence of weeds in the diazinon-treated (15\%) than Serratia-treated and control plots (30\% and $31 \%$, respectively). There was no significant difference in the presence of clover between the treatments at any of the three sites.

\section{DISCUSSION}

The results clearly demonstrated the value of a biological treatment for controlling the intransigent pasture pest, New Zealand grass grub.
Both Serratia and diazinon reduced grass grub populations for 2 years compared to the control. However, in the third year, grass grub populations increased rapidly in plots treated with diazinon, and were significantly greater than in plots treated with Serratia or left untreated. Serratiatreatment markedly increased the incidence of amber disease throughout the trial, compared to the diazinon-treated plots, and it is likely that the high level of disease contributed to the lower grass grub populations in the Serratia treatment for year 3. Following application of diazinon, there was little or no amber disease in the remaining larval population to provide ongoing regulation in subsequent years, and populations began to increase. These results highlight differences in mechanisms of grass grub control: diazinon is a relatively short-lived toxin - it produces mortality in the year of application but has no carry over effect. In contrast, S. entomophila is a bacterium that establishes in the soil and cycles through the larvae - it therefore has an enduring suppressive effect on grass grub populations.

Diazinon is commonly used to manage insect pests in New Zealand pastures because of its high

Table 2 Levels of Serratia entomophila (cfu/g soil) measured in soil of Serratia-treated, diazinon-treated and control plots for the three sites in 2010, 1 year after the application of treatments. Values are Mean \pm SEM. Treatments followed by the same letter are not significantly different $(\mathrm{P}>0.05)$ for each site.

\begin{tabular}{lccc}
\hline & Site 3B21 & Site 2A11 & WSite 2A13 \\
\hline Serratia & $2130 \pm 980 \mathrm{a}$ & $44700 \pm 29300 \mathrm{a}$ & $3540 \pm 2130 \mathrm{a}$ \\
Diazinon & $0 \pm 0 \mathrm{~b}$ & $0 \pm 0 \mathrm{~b}$ & $24.3 \pm 24.3 \mathrm{~b}$ \\
Control & $213 \pm 213 \mathrm{ab}$ & $91300 \pm 54700 \mathrm{ab}$ & $18.1 \pm 18.1 \mathrm{c}$ \\
\hline
\end{tabular}

Table 3 Score of visual damage (Scale: $1=$ no damage, $10=$ whole of plot damaged) or pasture vigour (Scale: $1=$ least vigorous, 3 = most vigorous) estimated on the three sites in May 2010 and/or May 2011. Values are Mean \pm SEM.

\begin{tabular}{|c|c|c|c|c|}
\hline \multirow[b]{3}{*}{ Treatment } & \multicolumn{3}{|c|}{ Visual damage } & \multirow{3}{*}{$\begin{array}{c}\text { Vigour } \\
2011 \\
2 \mathrm{~A} 13 \\
\end{array}$} \\
\hline & \multirow{2}{*}{$\begin{array}{l}2010 \\
3 B 21 \\
\end{array}$} & \multicolumn{2}{|c|}{2011} & \\
\hline & & 3B21 & $2 \mathrm{~A} 11$ & \\
\hline Serratia & $3.0 \pm 0.7$ & $2.3 \pm 0.4$ & $2.5 \pm 0.9$ & $2.5 \pm 0.5$ \\
\hline Diazinon & $2.0 \pm 0.7$ & $5.8 \pm 0.8$ & $6.0 \pm 0.9$ & $2.0 \pm 0.0$ \\
\hline Control & $5.4 \pm 0.7$ & $4.5 \pm 1.8$ & $5.0 \pm 0.2$ & $1.5 \pm 0.5$ \\
\hline
\end{tabular}


level of effectiveness, rapid action and low cost (Park et al. 2010). However, alternative control measures are needed to prepare for the withdrawal of organophosphates from international markets following de-registration of toxic pesticides in many jurisdictions around the world (Chapman \& Jackson 2010; Environmental Protection Authority 2016). In addition, the phenomenon of pest resurgence, whereby a pest population rebounds to equal or greater numbers than before pesticide use, must be considered. This has been well documented, including for grass grub in New Zealand (Lauren et al. 1990). Resurgence has often been attributed to elimination of predators and other natural enemies, such as insect pathogens (Hardin et al. 1995). Since resurgence can result in an unexpected increase in pest abundance compared with untreated populations, it is likely that the pest will cause greater than expected crop losses. However, crop losses specifically attributable to resurgence are rarely measured.

Long-term protection of pasture from grass grub damage is most likely to be achieved by the use of control measures that do not cause resurgence, such as Bioshield ${ }^{\mathrm{m} x}$, which maintains beneficial predators and insect pathogens in the soil. Levels of $S$. entomophila measured in soil in the year following treatment varied widely between treatments, with only the Serratia treatment maintaining soil populations of the insect pathogen at levels required to suppress the grass grub population at all sites $\left(>10^{4} S\right.$. entomophila per g soil; (O'Callaghan et al. 1999)). The almost complete absence of $S$. entomophila in soil treated with diazinon indicates a high likelihood of grass grub population resurgence, which was observed. Detection of S. entomophila in control plots is common in the years after treatment, owing to the natural spread of the pathogen and it will have contributed to grass grub population suppression in control plots in the years after the initial treatment (O'Callaghan \& Jackson 1993b).

The effects of the Serratia and diazinon treatments on pasture damage, vigour and composition were estimated towards the end of the trial. In agreement with relative grass grub populations in the second year, visual damage to pasture at the 3B21 site was significantly less in the Serratia- and diazinon-treated plots than the control. By the third year, damage in diazinontreated plots had increased and vigour was lower than in the Serratia-treated plots. The pasture composition in the third year was also affected by the treatments, but there was significant variability between the sites. Serratia-treated plots tended to have more productive species (e.g. ryegrass) and fewer weeds than control and diazinon-treated plots. No measurements were made to assess pasture production losses from grass grub infestation and the effects of the treatments on reducing these losses.

In integrated pest management systems, applications of control measures are typically determined by sampling and the use of economic thresholds. This approach depends on the accurate prediction of expected losses, because controls must be applied before the loss occurs; prediction of damage and pest abundance therefore form the basis of effective strategies. Previous research on production losses due to grass grub infestation has been summarised (Garnham \& Barlow 1993), but these data relate to now out-dated pasture cultivars and farming systems and should be revised. Zydenbos et al. (2013) developed a decision support tool to help farmers identify which of their paddocks are likely to be affected by grass grub and provided guidelines on potential treatment thresholds. For example, if pastures were in grass grub-prone areas, on medium to light soils, 2-4 years since sowing after cultivation and grass grub populations are $100-300$ larvae $/ \mathrm{m}^{2}$ in February or March, treatment with a biological control such as S. entomophila is recommended.

In conclusion, single applications of chemical insecticides such as diazinon will not provide long-term control of grass grub larvae in pastures. In the future, this type of chemical treatment is unlikely to be available to pastoral farmers as synthetic pesticides are being de-registered in response to consumer demands and regulatory pressures that call for the removal of all chemicals from the food chain. A more sustainable option is the application of microbial control agents, such as S. entomophila, which can limit grass grub 
population outbreaks after disruptive events like cultivation. Future research should focus on quantifying farm-scale benefits of microbial control agents under modern farming systems.

\section{ACKNOWLEDGEMENTS}

Ballance Agri-Nutrients for supply of the Serratia formulation as Bioshield ${ }^{\mathrm{Tn}}$ and for assistance with funding for the trials. Funding was also contributed by two New Zealand Ministry of Business, Innovation and Employment programmes: Ecosystems Bioprotection (LINX0807) and Next Generation Biopesticides (C10X1310). Landcorp Farming Limited for access to Rangitaiki Station on which the trials were carried out. Thanks to AgResearch staff, Derrick Wilson, Sandra Young and Charlie Dillimore, who assisted with field sampling and laboratory analyses.

\section{REFERENCES}

AgPest 2016. Grass-grub, brown beetle larvae Scientific name: Costelytra zealandica http:// agpest.co.nz/?pesttypes=grass-grub-brownbeetle-larvae (accessed 12 May 2016).

Chapman RB, Jackson TA 2010. Implications of registered insecticide reassessment for pasture pest management. New Zealand Plant Protection 63: 272 (Abstract only).

East R, Kain WM 1982. Prediction of grass grub, Costelytra zealandica, (Coleoptera: Scarabaeidae) populations. New Zealand Entomologist 7: 222-226.

Environmental Protection Authority 2016. Hazardous Substances Update: April 2016 http://www.epa.govt.nz/news/news/Pages/ Read-the-Hazardous-Substances-UpdateApril-2016.aspx (accessed 12 May 2016).

Fraser TJ, Dennis S, Moss RA, Tozer KN, Stocker NR, Taylor AL, Faville MJ, Smith C 2011. Long term effect of superphosphate fertilisers on pasture persistence. Pasture Persistence Symposium. Grassland Research and Practice Series No. 15. New Zealand Grassland Association, Hamilton, New Zealand. Pp. 9397.
Garnham ML, Barlow ND 1993. Defining the cost of grass grub. In: Prestidge RA ed. Proceedings of the 6th Australasian Grasslands Invertebrate Ecology Conference. Pp. 32-38

Glare TR, O'Callaghan M, Wigley PJ 1993. Checklist of naturally occurring entomopathogenic microbes and nematodes in New Zealand. New Zealand Journal of Zoology 20: 95-120.

Hardin MR, Benrey B, Coll M, Lamp WO, Roderick GK, Barbosa P 1995. Arthropod pest resurgence: an overview of potential mechanisms. Crop Protection 14: 3-18.

Jackson TA, Saville DJ 2000. Bioassays of replicating bacteria against soil-dwelling insect pests. Chapter 2. In: Navon A, Ascher KRS eds. Bioassays of entomopathogenic microbes and nematodes. CABI, ISBN: 0851994229. Pp. 73-94.

Jackson TA, Huger AM, Glare TR 1993. Pathology of amber disease in the New Zealand grass grub Costelytra zealandica Coleoptera:Scarabaeidae). Journal of Invertebrate Pathology 61: 123-130.

Jackson TA, Pearson JF, O'Callaghan M, Mahanty HK, Willcocks MJ 1992. Pathogen to product - Development of Serratia entomophila (Enterobacteriaceae) as a commercial biological agent for the New Zealand grass grub Costelytra zealandica. In: Jackson TA, Glare TR eds. Use of Pathogens in Scarab Pest Management. Intercept, Andover. Pp. 191198.

Jackson TA, Townsend RJ, Dunbar JE, Ferguson CM, Marshall SDG, Zydenbos SM 2012. Anticipating the unexpected - managing pasture pest outbreaks after large-scale land conversion. Proceedings of the New Zealand Grassland Association 74: 153-158.

Johnson VW, Pearson JF, Jackson TA 2001. Formulation of Serratia entomophila for biological control of grass grub. New Zealand Plant Protection 54: 125-127.

Lauren DR, Henzell RF, Wrenn NR 1990. Grass grub (Costelytra zealandica) population trends following insecticide applications. New 
Zealand Journal of Agricultural Research 33: 159-163.

O’Callaghan M, Jackson TA 1993a. Isolation and enumeration of Serratia entomophila - a bacterial pathogen of the New Zealand grass grub, Costelytra zealandica. Journal of Applied Bacteriology 75: 307-314.

O’Callaghan M, Jackson TA 1993b. Adult grass grub dispersal of Serratia entomophila. Proceedings of the 46th New Zealand Plant Protection Conference. Pp. 235-236

O’Callaghan M, Young SD, Barlow ND, Jackson TA 1999. The ecology of grass grub pathogenic Serratia spp. in New Zealand pastures. Proceedings of the 7th Australasian Conference on Grassland Invertebrate Ecology. Pp. 85-91

Park NM, Walker JTS, Walker GP, Shaw PW, Wallis DR 2010. Diazinon use in New Zealand horticulture. Plant \& Food Research Client Report No. 38240 prepared for ERMA New Zealand http://www.epa.govt.nz/ search-databases/HSNO\%20Application $\% 20$ Register\%20Documents/ERMA200398_ Appendix \% 20L \% 20-\%20 Report $\% 20$ from $\% 20$ Plant $\% 20$ and $\% 20$ Food $\% 20$ Research.pdf (accessed 12 May 2016). Plant \& Food Research, Auckland, New Zealand. $78 \mathrm{pp}$.
Townsend RJ, Jackson TA, Ferguson CM, Proffitt JR, Slay MWA, Swaminathan J, Day S, Gerard EM, O'Callaghan M, Johnson VW 2004. Establishment of Serratia entomophila after application of a new formulation for grass grub control. New Zealand Plant Protection 57: 310-313.

Zydenbos SM, Ferguson CM, Townsend RJ, Dunbar JE, Peoples S, Willoughby BE, Lane PMS, Jackson TA 2013. Decision tools for managing insect pest outbreaks in pastures. Proceedings of the New Zealand Grassland Association 75: 103-112.INTRODUCTION 